\title{
ANTI-DIABETIC EFFECTS OF TURMERIC IN ALLOXAN INDUCED DIABETIC RATS.
}

Jeevangi Santoshkumar, S. Manjunath, Deepak D. Mariguddi, Prakash G. Kalashetty, Prashant Dass, Chetan Manjunath

1. Associate Professor. Department of Pharmacology, M.R. Medical College, Gulbarga.

2. Professor. Department of Pharmacology, S. Nijalingappa Medical College, Bagalkot

3. Post Graduate Student/Tutor. Department of Pharmacology, M.R. Medical College. Gulbarga.

4. Professor \& Head. Department of Pharmacology, K.B.N Medical College. Gulbarga

5. Post Graduate Student/Tutor. Department of Pharmacology, M.R. Medical College. Gulbarga.

6. Lecturer. Department of Pharmacology, H. K. E. College of Pharmacy. Gulbarga.

\section{CORRESPONDING AUTHOR:}

Dr. Jeevangi Santoshkumar,

Associate Professor,

Department of Pharmacology,

M. R. Medical College,

Gulbarga- 585105, Karnataka, India.

E-mail: drsantoshkumar.2007@rediffmail.com,djeevangi@gmail.com

Ph: 00919945910158

ABSTRACT: OBJECTIVE AND BACKGROUND: Turmeric (Curcuma longa) is one of the common constituents of our daily food. The present study was undertaken to evaluate the anti-diabetic effects of ethanolic extract of Rhizomes of curcuma longa in alloxan induced diabetic rats and compared with of Pioglitazone, which is the standard anti-diabetic agent. METHODS: Alloxan monohydrate is used to induce diabetes mellitus in albino rats in the dose of $120 \mathrm{mg} / \mathrm{kg}$ i.p. and anti-diabetic activity of turmeric was studied by following study design.

The rats are divided into 6 groups and each group contains 6 rats $(\mathrm{N}=6)$ as follows.

Group I: Normal control

Given normal saline $(10 \mathrm{ml} / \mathrm{kg} /$ day $)$.

Group II: Diabetic control

Given normal saline $(10 \mathrm{ml} / \mathrm{kg} /$ day $)$.

Group III: Euglycemic rats

Given turmeric extract $(300 \mathrm{mg} / \mathrm{kg} /$ day $)$.

Group IV: Diabetic rats

Given turmeric extract $(300 \mathrm{mg} / \mathrm{kg} /$ day).

Group V: Diabetic control

Given turmeric extract $(500 \mathrm{mg} / \mathrm{kg} /$ day $)$.

Group VI: Diabetic rats

Given Pioglitazone $(6 \mathrm{mg} / \mathrm{kg} /$ day)

Study was conducted for a period of 28 days and all the drugs were given orally once daily. Blood glucose levels were estimated at 1, 3, 5, 7 hrs. (acute study) and 7, 14, 21, 28 days (chronic study). The body weights of the rats in every groups recorded weekly and general behavior and health of the animal were monitored carefully. The data was analyzed statistically using student's paired and unpaired t-test. RESULTS: Ethanolic extract of turmeric produced significant $(\mathrm{p}<005)$ decreases in blood glucose levels on $7^{\text {th }}, 14^{\text {th }}, 21^{\text {th }}$ and 28 days in diabetic 
rats but there was no significant reduction in blood glucose levels after $1 \mathrm{hr}, 3 \mathrm{hrs}$, $5 \mathrm{hrs}$ and $7 \mathrm{hrs}$ after single dose of administration of turmeric extract. CONCLUSION: Present study revealed that curcuma longa possesses anti-diabetic activity can used to treat diabetes patients.

KEY WORDS: Curcuma longa, Turmeric, Alloxan-induced rats, Pioglitazone, Diabetes mellitus.

INTRODUCTION: Diabetes mellitus is a chronic metabolic disorder characterized by hyperglycemia resulting from defect in insulin secretion, insulin action or both. It is associated with high morbidity and mortality from long-term micro vascular and macro vascular complication.

Diabetes mellitus is among the most common endocrine disorder in developed and developing countries and has become major health problem in the modern world .India is the diabetic capital of the world. India leads the world with largest number of diabetic patients i.e. 40.9 million in the year 2007 and is predicted to rise to 69.9 million by the year 20251. In the world, for every $10^{\text {th }}$ second 2 persons will develop diabetes and 1 person dies from diabetes related causes. There is increased risk of atherogenic dyslipidemia and hypertension in diabetes; hence increases prevalence of coronary artery disease, heart failure, stroke in diabetic population².

Despite the availability of many medications to treat diabetes mellitus, still we are unable to check the growing incidence and prevalence of this modern pandemic. The currently available anti diabetic drugs have number of adverse effects. ${ }^{3}$ so there is increased demand for herbal / natural products which are supposed to have no or less side effects. Also, following the recommendation of WHO expert committee on diabetes mellitus on beneficial uses of medicinal plants in the treatment of diabetes mellitus, research on medicinal plants has gained the momentum ${ }^{4}$.

Indian traditional medicine is one of the richest medicinal systems among those available around the world. It is important to know that the oral hypoglycemic drug metformin was discovered from the traditional plant Galega ethlinasis or Galega officinalis 5 .Earliest description of curative properties of medicinal plants found in Rig Veda ( 2500-1800 BC ). Charaka Samhita ${ }^{6}$ and Sushruta Samhita ${ }^{7}$ give extensive description on various medicinal herbs. Turmeric is well known condiment in the world. It is a prime ingredient in curry powder and figures heavenly in Asian cuisines, aptly known as "Golden spice" of India .Turmeric plants were cultivated by Harappan civilization in 3000 BC. Turmeric is extensively used in Ayurveda, Unani and Siddha medicinal systems since from Vedic-ages and also as home remedy for various ailments. It is also used in Indian ritual and worship.

Turmeric is host of medical properties with its wide spectrum of actions ${ }^{8}$ such as Antiinflammatory ${ }^{9}$, anti-fungal ${ }^{10}$, anti-mutagenic ${ }^{11}$, anti-carcinogenic ${ }^{12}$, anti-coagulant ${ }^{13}$, antihepatotoxic ${ }^{14}$, anti-fertility ${ }^{15}$, anti-protozoa ${ }^{16}$, anti-viral ${ }^{17}$, anti-fibrotic ${ }^{18}$, anti-venom ${ }^{19}$, antiulcer $^{20}$, anti-hypertensive 21 , anti-diabetic 22,23 and hypo-cholesterolemic ${ }^{24}$ / hypo-lipid emic properties $^{25}$.Recently explored uses Alzheimer's disease ${ }^{26}$, Rheumatoid arthritis ${ }^{27}$, Multiple sclerosis ${ }^{28}$, Inflammatory bowel disease ${ }^{29}$, Cataract ${ }^{30}$ and HIV ${ }^{31}$.

The comparative study of anti-diabetic effects of turmeric extract with that of pioglitazone has not been documented. In the view of these reports, it seemed interesting to search for more efficient, safe and cost effective single anti-diabetic agent, which can also improve the lipid profile in diabetic patients. Hence the present is taken up to evaluate antidiabetic activity of ehanolic extract of turmeric in alloxan induced diabetic rats and compared with the effects of pioglitazone, which is the standard anti-diabetic agent ${ }^{32}$. 
MATERIALS AND METHODS: STUDY CENTER: The present study was carried out in the Postgraduate Research Laboratory Department of Pharmacology, M R Medical College, Gulbarga after obtaining the permission from the Institutional Animal Ethics Committee (HKES/MRMCG/256/2008 Dated 03/11/2008) of M.R. Medical College, Gulbarga.Karnataka.

Materials

1. Adult albino rats weighing 180-200 grams of either sex.

2. Glucometer and Strips (Accu-chek Active Glucometer, Roche Diagnostics, Germany).

3. Needle, Syringes, Feeding tubes, Rat holder.

4. Soxhlet Apparatus for preparing the Ethanol extraction of Turmeric.

5. Drugs-

a. Alloxan Monohydrate obtained from Otto Kemi Industry, Mumbai, India.

b. Ethanol Extract of Rhizomes of Turmeric.

c. Pioglitazone Hydrochloride (pure form) obtained from Bio-con Pharmaceuticals Bangalore.

d. Ethanol (99.99\%) of Changshu Yangyuan Chemicals, obtained from Venkatesh Chemicals, Gulbarga.

e. Vehicle: Normal Saline (0.9\%) and Tween80 (Hi Media Laboratories Pvt Ltd. Mumbai).

6. Proforma

Experimental Animals used in the study

- Study was carried out in healthy albino rats of Wister strain (Rattus norvegicus) of either sex.

- Body weight of all the animals was in the range of 180-200gms each.

- They were acclimatized to the laboratory conditions before carrying out experimental work in a well-ventilated animal house under natural photoperiod conditions for a period of 1 week.

- Total number of animals included in the study is 36, out of which diabetes was induced in 24 rats and 12 rats were euglycemic, housed separately in groups with distinct identity throughout the study in standard conditions of temperature and a 12 hours light-dark cycle.

- Sources: Animals were procured from Central Animal House, MR Medical College, Gulbarga, Karnataka.

- Diet: Animals were maintained on standard rat pellet diet. Water was given ad libitum during the entire period of the study.

- CPCSEA (Committee for the purpose of control and supervision of experiments on animals) Guidelines for laboratory animal facilities were strictly adhered 33,34 .

INDUCTION OF DIABETES MELLITUS: A single dose $(120 \mathrm{mg} / \mathrm{kg}$ i.p) of freshly prepared solution of Alloxan Monohydrate (dissolved in Normal Saline, Citrate buffer, pH 4.5) was administered to overnight fasting rats for induction of type-2 diabetes mellitus in the rats 35 . Control rats were similarly injected with normal saline. To prevent fatal hypoglycemia as a result of massive pancreatic insulin release, Alloxan administered rats were provided with $10 \%$ Glucose solution after 6 hours for next 24 hours. Fasting blood glucose level was checked after 48-72 hours when the animals became hyperglycemic reflected by glycosuria, hyperglycemia, polyphagia, polydipsia and progressive loss of body weight as compared with normal rats. Blood glucose levels between $200-350 \mathrm{mg} / \mathrm{dl}$ were selected as diabetic. 
PREPARATION OF EXTRACT ${ }^{36:}$ Fine powder of dry rhizomes of Turmeric was purchased from local market and was packed into thimble of filter paper and put in Soxhlet extractor in 5 batches of $200 \mathrm{gm}$ each and subjected to continuous extraction with $99.99 \%$ ethanol for about 48 hours at $60^{\circ} \mathrm{C}$ till solvent in the siphon tube becomes colorless and it took around 8-10 cycles/200 gram powder. Small porcelain pieces were added to the flask to avoid bumping of solvent. The solvent so obtained was distilled off and was heated evaporated using water bath /magnetic heart stirrer to get concentrated thick extract which is later diluted in Tween80 and administered to the rat by oral route once daily.

\section{EXPERIMENTAL DESIGN}

The experiment was carried out for a period of 28 days. For this purpose, 36 healthy albino rats were selected and grouped as follows:

Group I: Normal control

Given normal saline $(10 \mathrm{ml} / \mathrm{kg} /$ day $)$.

Group II: Diabetic control

Given normal saline $(10 \mathrm{ml} / \mathrm{kg} /$ day $)$.

Group III: Euglycemic rats

Given turmeric extract $(300 \mathrm{mg} / \mathrm{kg} /$ day).

Group IV: Diabetic rats

Given turmeric extract $(300 \mathrm{mg} / \mathrm{kg} /$ day).

Group V: Diabetic control

Given turmeric extract $(500 \mathrm{mg} / \mathrm{kg} /$ day $)$.

Group VI: Diabetic rats

Given Pioglitazone $(6 \mathrm{mg} / \mathrm{kg} /$ day)

Body weight of rats in every group was recorded weekly. Experimental rats were carefully monitored every day for general health and behavior.

Study was carried out in 2 phases to assess acute and chronic effect of Turmeric extract in euglycemic and hyperglycemic rats.

Acute study: After a single dose administration of Turmeric extract, blood samples were collected and estimated for blood glucose levels at the end of $0,1,3,5$ and 7 hours by using glucometer.

Chronic study: Treatment was continued for 28 days with once daily administration of Turmeric extract. Blood glucose levels were estimated at the end of 7, 14, 21, and 28 days.

ORAL ADMINISTRATION OF EXTRACT /DRUG: As ethanol extract of Turmeric and Pioglitazone were insoluble in water, they are suspended in 5\% Tween80 (w/v), administered orally according to the dosage in the respective groups using an intra-gastric feeding tube.

Method of collection of blood samples: Tail cut method from tip of the rat tail ${ }^{37}$.

Estimation of blood glucose

Blood glucose estimation was done by using Accu-chek Active glucometer. It uses glucose oxidase specific strips and works on principle called as Reflectance Photometry. It is easy to use, quick to perform and reliable. There is a reasonable co-relation between laboratory results and those obtained with glucometer ${ }^{38}$. 
The test strip is inserted into the glucometer and the blood sample is directly placed on the strip. The result i.e., blood glucose level appeared on the screen within a few seconds in $\mathrm{mg} / \mathrm{dl}$.

STATISTICS: The results were analyzed by employing the Paired 't' test and the Unpaired' test.

RESULTS: The study was carried out to evaluate the effects of ethanol extract of Turmeric on blood glucose levels in Alloxan induced diabetic albino rats.

Table I Effect of ethanolic extract of Turmeric on blood glucose levels of euglycemic rats (Group III)

\begin{tabular}{|l|l|l|l|l|l|l|l|l|l|}
\hline Rat & 0 hrs. & $1 \mathrm{hrs}$ & $3 \mathrm{hrs}$ & $5 \mathrm{hrs}$ & $7 \mathrm{hrs}$ & 7 days & 14 days & 21 days & 28days \\
\hline 1 & 96 & 94 & 90 & 88 & 94 & 90 & 90 & 86 & 88 \\
\hline 2 & 86 & 88 & 96 & 89 & 90 & 92 & 94 & 92 & 90 \\
\hline 3 & 92 & 90 & 88 & 85 & 84 & 90 & 92 & 90 & 91 \\
\hline 4 & 98 & 92 & 90 & 99 & 90 & 96 & 90 & 89 & 84 \\
\hline 5 & 90 & 91 & 92 & 86 & 88 & 87 & 92 & 93 & 88 \\
\hline 6 & 93 & 90 & 94 & 88 & 89 & 88 & 90 & 90 & 90 \\
\hline $\begin{array}{l}\text { Mean } \\
\pm \text { SD }\end{array}$ & $\begin{array}{l}92.5 \\
\pm 4.9\end{array}$ & $\begin{array}{l}90.8 \\
\pm 1.9\end{array}$ & $\begin{array}{l}91.66 \\
\pm 2.68\end{array}$ & $\begin{array}{l}89.2 \\
\pm 4.6\end{array}$ & $\begin{array}{l}89.6 \\
\pm 2.9\end{array}$ & $\begin{array}{l}90.5 \\
\pm 2.92\end{array}$ & $\begin{array}{l}91.3 \\
\pm 1.49\end{array}$ & $\begin{array}{l}90 \\
\pm 2.4\end{array}$ & $\begin{array}{l}88.58 \\
\pm 3.29\end{array}$ \\
\hline $\begin{array}{l}\text { 't' test value } \\
\text { comparing } \\
\text { with 0 hour }\end{array}$ & 0.79 & 0.38 & 1.18 & 1.26 & 0.86 & 0.58 & 1.14 & 1.63 \\
\hline \begin{tabular}{l} 
P value \\
\hline
\end{tabular}
\end{tabular}

By the data analysis, it is very clear that Turmeric extract $(300 \mathrm{mg} / \mathrm{kg})$ has no statistically significant effect on blood glucose levels of euglycemic rat.

By using paired ' $\mathrm{t}$ ' test when we compared the initial values (at 0 hour) with 1 hour , 3 hour, 5 hour, 7 hour, 7 days, 14 days, 21 days and 28 days and $p$ values at all the time intervals found to be $>0.05$, i.e. statistically not significant.

Table -II Effect of ethanolic extract of Turmeric $300 \mathrm{mg} / \mathrm{kg}$ on blood glucose levels of diabetic rats (Group IV)

\begin{tabular}{|l|l|l|l|l|l|l|l|l|l|}
\hline Rat & $0 \mathrm{hrs}$. & $1 \mathrm{hrs}$ & $3 \mathrm{hrs}$ & $5 \mathrm{hrs}$ & $7 \mathrm{hrs}$ & 7 days & 14 days & 21days & 28days \\
\hline 1 & 290 & 282 & 270 & 280 & 265 & 280 & 200 & 180 & 130 \\
\hline 2 & 285 & 278 & 275 & 260 & 282 & 290 & 235 & 198 & 138 \\
\hline
\end{tabular}




\begin{tabular}{|l|l|l|l|l|l|l|l|l|l|}
\hline \hline 3 & 312 & 295 & 289 & 268 & 272 & 255 & 212 & 218 & 140 \\
\hline 4 & 270 & 312 & 263 & 282 & 290 & 294 & 230 & 208 & 152 \\
\hline 5 & 248 & 240 & 259 & 239 & 242 & 220 & 240 & 180 & 158 \\
\hline 6 & 292 & 284 & 270 & 242 & 230 & 198 & 198 & 192 & 130 \\
\hline $\begin{array}{l}\text { Mean } \\
\pm \text { SD }\end{array}$ & $\begin{array}{l}282.17 \\
\pm 19.76\end{array}$ & $\begin{array}{l}281.86 \\
\pm 21.8\end{array}$ & $\begin{array}{l}271 \\
\pm 9.57\end{array}$ & $\begin{array}{l}261.8 \\
\pm 16.7\end{array}$ & $\begin{array}{l}262.8 \\
\pm 20.51\end{array}$ & $\begin{array}{l}256.16 \\
\pm 36.14\end{array}$ & $\begin{array}{l}219.16 \\
\pm 16.85\end{array}$ & \pm 14.2 & \pm 10.49 \\
\hline $\begin{array}{l}\text { 't' test value } \\
\text { comparing with } \\
0 \text { hour }\end{array}$ & 0.04 & 1.25 & 1.94 & 1.66 & 1.74 & 5.88 & 8.64 & 15.41 \\
\hline \begin{tabular}{l} 
P value \\
\hline
\end{tabular} & $\begin{array}{l}\mathrm{P}> \\
0.05\end{array}$ & $\begin{array}{l}\mathrm{P}> \\
0.05\end{array}$ & $\begin{array}{l}\mathrm{P}> \\
0.05\end{array}$ & $\begin{array}{l}\mathrm{P}> \\
0.05\end{array}$ & $\begin{array}{l}\mathrm{P}> \\
0.05\end{array}$ & $\begin{array}{l}\mathrm{P}< \\
0.01\end{array}$ & $\begin{array}{l}\mathrm{P}< \\
0.001\end{array}$ & $\begin{array}{l}\mathrm{P}< \\
0.001\end{array}$ \\
\hline
\end{tabular}

Turmeric extract $(300 \mathrm{mg} / \mathrm{kg}$ ) has no significant effect on blood glucose levels of diabetic rats in acute study (i.e. $1 \mathrm{hr}, 3 \mathrm{hr}, 5 \mathrm{hr}, 7 \mathrm{hr}$ and 7 days). Turmeric controls the blood glucose only in the acute diabetic rats but not in the chronic diabetic rats in lower dose i.e.300mg $/ \mathrm{kg} /$ day. By using paired ' $\mathrm{t}$ ' test, when we compared the initial values at 0 hour with $1 \mathrm{hr}, 3 \mathrm{hr}, 5 \mathrm{hr}, 7 \mathrm{hr}, 7$ days and $\mathrm{p}$ value at all the time intervals found to be $>0.05$, i.e. statistically not significant. In the chronic study, i.e. 14 days $p<0.01,21$ days and 28 days $p<0.001$ i.e. very highly significant.

Table III Effect of ethanolic extract of Turmeric $500 \mathrm{mg} / \mathrm{kg}$ on blood glucose levels of diabetic rats (Group V)

\begin{tabular}{|l|l|l|l|l|l|l|l|l|l|}
\hline Rat & 0 hrs. & $1 \mathrm{hrs}$ & $3 \mathrm{hrs}$ & $5 \mathrm{hrs}$ & $7 \mathrm{hrs}$ & 7 days & 14 days & 21 days & 28 days \\
\hline 1 & 297 & 295 & 282 & 286 & 290 & 230 & 225 & 180 & 125 \\
\hline 2 & 302 & 286 & 293 & 298 & 240 & 223 & 186 & 170 & 130 \\
\hline 3 & 298 & 280 & 275 & 232 & 200 & 191 & 158 & 162 & 108 \\
\hline 4 & 248 & 269 & 292 & 294 & 258 & 196 & 175 & 152 & 98 \\
\hline 5 & 262 & 262 & 284 & 208 & 220 & 200 & 180 & 145 & 105 \\
\hline 6 & 290 & 280 & 268 & 226 & 220 & 182 & 160 & 128 & 118 \\
\hline
\end{tabular}




\begin{tabular}{|l|l|l|l|l|l|l|l|l|l|}
\hline $\begin{array}{l}\text { Mean } \\
\pm \text { SD }\end{array}$ & $\begin{array}{l}282.83 \\
\pm 20.39\end{array}$ & $\begin{array}{l}278.66 \\
\pm 10.76\end{array}$ & $\begin{array}{l}282.33 \\
\pm 8.84\end{array}$ & $\begin{array}{l}257.34 \\
\pm 36.4\end{array}$ & $\begin{array}{l}252.1 \\
\pm 29.26\end{array}$ & $\begin{array}{l}203.6 \\
\pm 17.17\end{array}$ & $\begin{array}{l}180.66 \\
\pm 22.23\end{array}$ & $\begin{array}{l}156.60 \\
\pm 16.98\end{array}$ & $\begin{array}{l}114.12 \\
\pm 1.29\end{array}$ \\
\hline $\begin{array}{l}\text { 't' test value } \\
\text { comparing with } \\
0 \text { hour }\end{array}$ & 0.44 & 0.055 & 1.49 & 2.11 & 7.28 & 8.27 & 11.69 & 15.33 \\
\hline P value & $\begin{array}{l}\mathrm{P} \\
0.05\end{array}$ & $\begin{array}{l}\mathrm{P}> \\
0.05\end{array}$ & $\begin{array}{l}\mathrm{P}> \\
0.05\end{array}$ & $\begin{array}{l}\mathrm{P}> \\
0.05\end{array}$ & $\begin{array}{l}\mathrm{P}< \\
0.001\end{array}$ & $\begin{array}{l}\mathrm{P}< \\
0.001\end{array}$ & $\begin{array}{l}\mathrm{P}< \\
0.001\end{array}$ & 0.001 \\
\hline
\end{tabular}

Turmeric extract $(500 \mathrm{mg} / \mathrm{kg}$ ) has no significant effect on blood glucose levels of diabetic rats in acute study i.e. $1 \mathrm{hr}$., $3 \mathrm{hr}$., $5 \mathrm{hr}$., $7 \mathrm{hr}$. By using paired ' $\mathrm{t}$ ' test when we compared initial values at $0 \mathrm{hr}$. with $1 \mathrm{hr}$., $3 \mathrm{hr}$., $5 \mathrm{hr}$., $7 \mathrm{hr}$. and p values at all the time intervals found to be $>0.05$ i.e. statistically not significant. In chronic study i.e. 7 days to 28 days, $p$ value $<0.001$ i.e. very highly significant.

Table IV Effect of Pioglitazone 6mg/kg on blood glucose levels of diabetic rates (Group VI)

\begin{tabular}{|l|l|l|l|l|l|l|l|l|l|}
\hline Rat & 0 hrs. & $1 \mathrm{hrs}$ & $3 \mathrm{hrs}$ & $5 \mathrm{hrs}$ & $7 \mathrm{hrs}$ & 7 days & 14 days & 21 days & 28 days \\
\hline 1 & 300 & 294 & 280 & 210 & 178 & 146 & 120 & 102 & 99 \\
\hline 2 & 292 & 282 & 265 & 200 & 205 & 118 & 112 & 116 & 106 \\
\hline 3 & 287 & 276 & 280 & 208 & 200 & 122 & 117 & 114 & 112 \\
\hline 4 & 243 & 240 & 200 & 200 & 210 & 110 & 118 & 98 & 90 \\
\hline 5 & 295 & 282 & 262 & 216 & 222 & 132 & 122 & 118 & 94 \\
\hline 6 & 276 & 256 & 240 & 206 & 202 & 112 & 128 & 113 & 108 \\
\hline $\begin{array}{l}\text { Mean } \\
\pm \text { SD }\end{array}$ & $\begin{array}{l}282.03 \\
\pm 19.13\end{array}$ & $\begin{array}{l}271.66 \\
\pm 18.16\end{array}$ & $\begin{array}{l}254.86 \\
\pm 26.12\end{array}$ & $\begin{array}{l}206.6 \\
\pm 9.6\end{array}$ & $\begin{array}{l}202.28 \\
\pm 13.22\end{array}$ & $\begin{array}{l}120 \\
\pm 7.6\end{array}$ & $\begin{array}{l}119.5 \\
\pm 4.89\end{array}$ & $\begin{array}{l}110.16 \\
\pm 7.44\end{array}$ & $\begin{array}{l}101.5 \\
\pm 7.8\end{array}$ \\
\hline $\begin{array}{l}\text { 't' test value } \\
\text { comparing with } \\
0 \text { hour }\end{array}$ & 0.96 & 1.94 & 8.62 & 8.43 & 19.28 & 20.26 & 20.70 & 21.48 \\
\hline \begin{tabular}{l} 
P value \\
\hline
\end{tabular} & $\begin{array}{l}\mathrm{P} \\
0.05\end{array}$ & $\begin{array}{l}\mathrm{P}> \\
0.05\end{array}$ & $\begin{array}{l}\mathrm{P}< \\
0.001\end{array}$ & $\begin{array}{l}\mathrm{P}< \\
0.001\end{array}$ & $\begin{array}{l}\mathrm{P}< \\
0.001\end{array}$ & $\begin{array}{l}\mathrm{P}< \\
0.001\end{array}$ & $\begin{array}{l}\mathrm{P}< \\
0.001\end{array}$ & $\begin{array}{l}\mathrm{P}< \\
0.001\end{array}$ \\
\hline
\end{tabular}

Pioglitazone has no significant effect on blood glucose levels of diabetic rats in acute study i.e. $1 \mathrm{hr}$ and $3 \mathrm{hr}$. By using paired ' $\mathrm{t}$ ' test, when we compared the initial values at $0 \mathrm{hr}$ with $1 \mathrm{hr}, 3 \mathrm{hr} \mathrm{p}$ values found to be $>0.05$ i.e. statistically not significant. But in chronic study after 21 days to 28 days pioglitazone has significant effect on blood glucose levels of diabetic rats in chronic study, $\mathrm{p}<0.001$, i.e. very highly significant.

Table $\mathrm{V}$ Recording of body weight changes in experimental rats at the end of every week

\begin{tabular}{|l|l|l|l|l|l|}
\hline & 0 days & 7 days & 14 days & 21 days & 28 days \\
\hline Group I & $221 \pm 2.6$ & $220 \pm 6.82$ & $223 \pm 8.5$ & $225 \pm 8.48$ & $225 \pm 9.8$ \\
\hline Group II & $202 \pm 3.6$ & $185 \pm 2.5$ & $180 \pm 1.8$ & $165 \pm 2.4$ & $161 \pm 6.9$ \\
\hline
\end{tabular}




\begin{tabular}{|l|l|l|l|l|l|}
\hline Group III & $210 \pm 5.84$ & $211 \pm 3.8$ & $213 \pm 4.3$ & $213.3 \pm 5.2$ & $213.4 \pm 6.96$ \\
\hline Group IV & $211 \pm 5.32$ & $210 \pm 3.86$ & $209 \pm 2.86$ & $206 \pm 4.36$ & $206 \pm 3.2$ \\
\hline Group V & $210 \pm 3.6$ & $208 \pm 3.6$ & $213 \pm 2.78$ & $214.8 \pm 3.6$ & $215.2 \pm 2.96$ \\
\hline Group VI & $208 \pm 3.2$ & $190 \pm 3.2$ & $212 \pm 2.3$ & $218 \pm 3.9$ & $221.2 \pm 6.52$ \\
\hline
\end{tabular}

In comparison of body weight at 0 days to 28 days,

Group I, $\mathrm{t}=1.98, \mathrm{p}>0.05$, i.e. not significant

Group II, $\mathrm{t}=25.62, \mathrm{p}<0.001$, i.e. very highly significant

Group III, $\mathrm{t}=1.72, \mathrm{p}>0.05$, i.e. not significant

Group IV, $\mathrm{t}=3.98, \mathrm{p}<0.05$, i.e. significant

Group V, $t=5.59, \mathrm{p}<0.01$, i.e. highly significant

Group VI, $t=9.12, p<0.001$, i.e. very highly significant

DISCUSSION: Diabetes Mellitus is the commonest endocrine disorder and is as old as mankind. Since Vedic period, many herbs have been in use for treating diabetes ${ }^{39}$. The current arsenal of anti-diabetic drugs is prone to many grave side effects. Therefore a need to develop safer herbal preparations is felt. Turmeric is a well-known condiment, which is used in our daily diet and has many medicinal properties. The present study is taken up to evaluate the anti- diabetic effect of Turmeric which is rich in active ingredient Curcumin. From the earlier studies, it was found that Turmeric is known to possess anti-diabetic properties ${ }^{40,41}$. Our standard anti diabetic drug, Pioglitazone, acts on PPAR- $\gamma$ which is present primarily in adipose tissue and less in cardiac, skeletal, smooth muscle cells, islet $\beta$ cells, macrophages and vascular endothelial cells. These are insulin sensitizer by nature and increase insulin mediated glucose uptake by $30-50 \%$ in patients with type 2 diabetes mellitus ${ }^{42}$. Current use anti diabetic drugs like our standard drug Pioglitazone comes attached with various side effects including development of life threatening conditions like bladder cancer and cardiovascular abnormalities on long term administration ${ }^{43}$. Main constituents of the extract viz Curcumin, Dimethoxy Curcumin, Bis-demethohoxy Curcumin and Arturmerone have PPAR- $\gamma$ ligand binding activity and thereby enhance the transcription of several insulin responsive genes and improve the insulin resistance in Type 2 Diabetes mellitus ${ }^{44}$. From our study we also conclude that turmeric in itself has shown to possess a euglycemic property which is very useful and convenient for diabetic patients. Studies suggest that the anti-diabetic action of Turmeric needs some preparations of functional islet $\beta$ cell mass ${ }^{45}$. So it is very helpful in treating type 2 diabetes than type 1 diabetes mellitus.

After single dose administration, Turmeric extract reduced blood glucose levels in all groups but the reduction was not statistically significant, thus suggesting it requires a longer duration for the onset of action.

It is found that Turmeric extract at a dose of $300 \mathrm{mg} / \mathrm{kg}$, has not significantly reduced the blood glucose levels in euglycemic group (Group III), suggesting that it has no significant effect on blood glucose levels in healthy rats. Turmeric extract $300 \mathrm{mg} / \mathrm{kg}$ has significantly reduced the blood glucose levels in diabetic rats from 7 th day onwards. But $500 \mathrm{mg} / \mathrm{kg}$ has more efficient action, as reduction in blood glucose levels was statistically highly significant. Pioglitazone which is a standard anti diabetic drug, reduced blood glucose by a highly significant level in both acute and chronic study.

CONCLUSION: Results obtained from the present study proved that ethanolic extract of Turmeric has anti diabetic and euglycemic action, hence Turmeric is proved to be a promising 
medicinal plant which can be used as an adjunct to drug and diet therapy for the management of diabetes mellitus.

\section{REFERENCES:}

1. Diabetes Epidemic Facts, International Diabetes Federation: Diabetes Atlas; 3rd Edition 2007 - cited on url. http://www.idf.org/home/index.

2. Kim HK, Kim $\mathrm{CH}$, Kim EH et al. Impaired fasting glucose and risk of cardiovascular disease in korean men and women: the korean heart study. Diabetes Care. 2013 Feb; 36(2): 328-35.

3. Hamilton CA. Pharmacological management of type 2 diabetes mellitus in patients with CKD. J Ren Care. 2012 Feb; 38 Suppl 1: 59-66.

4. Malviya N, Jain S, Malviya S. Antidiabetic potential of medicinal plants. Acta Pol Pharm. 2010 Mar-Apr; 67(2): 113-8.

5. Perla V, Jayanty SS. Biguanide related compounds in traditional antidiabetic functional foods. Food Chem. 2013 Jun 1; 138(2-3): 1574-80.

6. Jakhmola RK. Medicinal - Agricultural science in Vedic literature. Ayu. 2012 Jan; 33(1): 147-56.

7. Loukas M, Lanteri A, Ferrauiola J et al. Anatomy in ancient India: a focus on the Susruta Samhita. J Anat. 2010 Dec; 217(6): 646-50.

8. Gupta SC, Patchva S, Koh W et al. Discovery of curcumin, a component of golden spice, and its miraculous biological activities. Clin Exp Pharmacol Physiol. 2012 Mar; 39(3): 283-99.

9. Di Lorenzo C, Dell'agli M, Badea M et al. Plant Food Supplements with Anti-Inflammatory Properties: A Systematic Review (II). Crit Rev Food Sci Nutr. 2013; 53(5): 507-16.

10. Amphawan A, Nongnuch V, Duang B et al. Antifungal activity of turmeric oil extracted from Curcuma longa (Zingiberaceae). Journal of Ethnopharmacology Volume 49, Issue 3, 15 December 1995, Pages 163-169.

11. Soudamini KK, Unnikrishnan MC, Sukumaran K et al. Mutagenicity and anti-mutagenicity of selected spices. Indian J Physiol Pharmacol. 1995 Oct; 39(4): 347-53.

12. Sun XD, Liu XE, Huang DS. Curcumin induces apoptosis of triple-negative breast cancer cells by inhibition of EGFR expression. Mol Med Rep. 2012 Dec; 6(6): 1267-70.

13. Kim DC, Ku SK, Bae JS. Anticoagulant activities of curcumin and its derivative. BMB Rep. 2012 Apr; 45(4): 221-6.

14. Kuo JJ, Chang HH, Tsai $\mathrm{TH}$ et al. Curcumin ameliorates mitochondrial dysfunction associated with inhibition of gluconeogenesis in free fatty acid-mediated hepatic lipoapoptosis. Int J Mol Med. 2012 Sep; 30(3): 643-9.

15. Ghosh AK, Das AK, Patra KK. Studies on antifertility effect of rhizome of curcuma. Asian Journal of Pharmacy and Life Science. Vol. 1 (4), Oct-Dec, 2011.

16. Nayak A, Gayen P, Saini P, Mukherjee N et al. Molecular evidence of curcumin-induced apoptosis in the filarial worm Setaria cervi. Parasitol Res. 2012 Sep; 111(3): 1173-86.

17. Dong JY, Ma XY, Cai XQ et al. Sesquiterpenoids from Curcuma wenyujin with antiinfluenza viral activities. Phytochemistry. 2013 Jan; 85: 122-8.

18. Wang NP, Wang ZF, Tootle S et al. Curcumin promotes cardiac repair and ameliorates cardiac dysfunction following myocardial infarction. Br J Pharmacol. 2012 Dec; 167(7): 1550-62. 
19. Jacome D, Melo MM, Santos MM et al. Kinetics of venom and antivenom serum and clinical parameters and treatment efficacy in Bothrops alternatus envenomed dogs. Vet Hum Toxicol. 2002 Dec; 44(6): 334-8.

20. Koosirirat C, Linpisarn S, Changsom D et al. Investigation of the anti-inflammatory effect of Curcuma longa in Helicobacter pylori-infected patients. Int Immunopharmacol. 2010 Jul; 10(7): 815-8.

21. Adaramoye OA, Anjos RM, Almeida MM et al. Hypotensive and endotheliumindependent vasorelaxant effects of methanolic extract from Curcuma longa L. in rats. J Ethnopharmacol. 2009 Jul 30; 124(3): 457-62.

22. Halim EM, Ali H. Hypoglycemic, Hypolipidemic and Antioxidant properties of combination of curcumin from curcuma longa, Linn and partially purified product from Abroma agusta, Linn in Streptozocin induced diabetes. Ind J Clin Biochem. 2002; 17(2): 33-43.

23. Arun N, Nalini N. Efficacy of turmeric on blood sugar and polyol pathway in diabetic albino rats. Plant Foods Hum. Nutr, 2002; 57: 41-52.

24. Ramírez-Tortosa MC, Mesa MD et al. Oral administration of a turmeric extract inhibits LDL oxidation and has hypocholesterolemic effects in rabbits with experimental atherosclerosis. Atherosclerosis. 1999 Dec; 147(2): 371-8.

25. Zingg JM, Hasan ST, Meydani M. Molecular mechanisms of hypolipidemic effects of curcumin. Biofactors. 2013 Jan; 39(1): 101-21.

26. Calcul L, Zhang B, Jinwal UK et al. Natural products as a rich source of tau-targeting drugs for Alzheimer's disease. Future Med Chem. 2012 Sep; 4(13): 1751-61.

27. Taty Anna K, Elvy Suhana MR, Das S et al. Anti-inflammatory effect of Curcuma longa (turmeric) on collagen-induced arthritis: an anatomico-radiological study. Clin Ter. 2011; 162(3): 201-7.

28. Kim DS, Kim JY, Han Y. Curcuminoids in neurodegenerative diseases. Recent Pat CNS Drug Discov. 2012 Dec; 7(3): 184-204.

29. Baliga MS, Joseph N, Venkataranganna MV et al. Curcumin, an active component of turmeric in the prevention and treatment of ulcerative colitis: preclinical and clinical observations. Food Funct. 2012 Nov; 3(11): 1109-17.

30. Raju TN, Kumar CS, Kanth VR et al. Cumulative antioxidant defense against oxidative challenge in galactose-induced cataractogenesis in Wistar rats. Indian J Exp Biol. 2006 Sep; 44(9): 733-9.

31. Conteas CN, Panossian AM, Tran TT et al. Treatment of HIV-associated diarrhea with curcumin. Dig Dis Sci. 2009 Oct; 54(10): 2188-91.

32. Vinnik NI, Kutsenko LA, Kutsenko NL et al. The effectiveness of pioglitazone in the treatment of patients with coronary heart disease on the background of metabolic syndrome. Lik Sprava. 2011 Apr-Jun; (3-4): 71-8.

33. CPCSEA Guidelines for laboratory animal facility. Indian J Pharmacol, Special Article, Year: 2003; Volume: 35, Issue: 4 Page: 257-274.

34. Pereira S, Tettamanti M. Ahimsa and alternatives -- the concept of the 4th R. The CPCSEA in India. Altex 2005, 22(1): 3-6.

35. Ankur Rohilla, Shahjad Ali. Alloxan Induced Diabetes: Mechanisms and Effects. International Journal of Research in Pharmaceutical and Biomedical Sciences. Vol. 3 (2) Apr - Jun2012: 819-823. 
36. Hawthorne SB, Grabanski CB, Martin E et al. Comparisons of Soxhlet extraction, pressurized liquid extraction, supercritical fluid extraction and subcritical water extraction for environmental solids: recovery, selectivity and effects on sample matrix. Journal of Chromatography; Volume 892, Issues 1-2, 15 September 2000: Pages 421433.

37. Furuhama K, Onodera T. A simple technique for repeated blood collection from the tail vein of the rat. J Toxicol Sci. 1983 May; 8(2): 161-3.

38. Poirier J Y, Le Prieur N, Campion L et al. Clinical and statistical evaluation of selfmonitoring blood glucose meters. Diabetes Care November 1998 vol. 21 no. 11 19191924.

39. Subbulakshmi, G, Naik M. Indigenous foods in the treatment of diabetes mellitus. Bombay Hosp J; 2001 43(4): 548-61.

40. Gomes de D, Alegrio LV, DeLima ME et al. Synthetic derivatives of curcumin and their activity against Leishmania amazonensis. Arzneimittelforschung. 2002; 52: 120-124.

41. Kuroda M, Mimaki Y, Nishiyama T et al. Hypoglycemic effects turmeric (Curcuma longa L. Rhizomes) on genetically diabetic KK-Ar mice. Biol Pharm. Bull. 2005; 28(5): 937-939.

42. Powers AC, D'Alessio D. Endocrine Pancreas and Pharmacotherapy of Diabetes Mellitus and Hypoglycemia. Goodman \& Gilman's The Pharmacological Basis of Therapeutics $12^{\text {th }}$ Edition McGraw Hill Publications 2011; Chap 43: Pages 1237-1273.

43. Vijay Panikar. Pioglitazone and Bladder Cancer: The Pros and Cons. Jour Ass Phy Ind, Jan 2012; Vol 60: Pages 72-73.

44. Chattopadhyay I, Biswas K, Bandyopadhyay U et al. Turmeric and curcumin: Biological actions and medicinal applications. Current Science, Vol. 87, No. 1, 10 July 2004: Page 44-53.

45. Wickenberg J, Ingemansson SL, Hlebowicz J. Effects of Curcuma longa (turmeric) on postprandial plasma glucose and insulin in healthy subjects. Nutrition journal; 2010 $9(1): 43$. 